\title{
EFFORTS TO IMPROVE THE COMPETENCY OF PROFESSIONALISM TEACHER IN JEMBER REGENCY
}

\author{
Fahrudi Ahwan Ikhsan ${ }^{1}$, Fahmi Arif Kurnianto ${ }^{1}$, Bejo Apriyanto ${ }^{1}$, Elan Artono Nurdin ${ }^{1}$ \\ ${ }^{1}$ Departement of Geography Education \\ University of Jember, Indonesia \\ E-mail: ahwan.fkip@unej.ac.id
}

DOI: $10.19184 /$ geosi.v1i1.6191

\begin{abstract}
Article Info: Received Date $27^{\text {th }}$ November 2017, Received in revised from date $4^{\text {th }}$ December 2017, Accepted Date $7^{\text {th }}$ December 2017, Publish Date 14 $4^{\text {th }}$ December 2017
\end{abstract}

\begin{abstract}
This study aims to explain the condition of professionalism and efforts to improve the competence of teachers IPS in Jember District. The sampling technique was done by random sampling which amounted to 55 person. Methods of data collection with questionnaires and documentation. Data analysis uses a percentage descriptive. The result of the research shows that the competency of professionalism of IPS teachers is as follows: the acquisition of materials, concepts and scholarship of IPS teachers is $87.25 \%$ in the high category, the development of learning materials supported by IPS teachers creatively is $92.04 \%$ including in the high category; mastery of basic competence and basic competence by $87.05 \%$ including high category, utilization of communication technology for self-development of IPS teachers of $86.35 \%$ included in the high category. In general, the competency of professionalism of IPS teachers in Jember district is categorized as high, namely $88.17 \%$, while the effort to increase the professional competence of IPS teachers as follows: joining the training and seminar of $66.81 \%$ low category; developing syllabus and IPS RPP of $70.50 \%$; doing PTK $48.95 \%$ low category; develop science of technology in learning $74.82 \%$ high category. Overall, the effort to improve the professionalism competence of IPS Junior High School teachers in Jember District is 71.34 included in the high category.
\end{abstract}

Key words: Professionalism Competence, IPS Teachers

\section{INTRODUCTION}

Teacher competence is needed in learning and teaching process. It is because it is related to professional ethics which is done by the teacher. Competence is not just oriented to the skill to pursue something, but more than professionalism as a teacher. Competence will influence the personality and development of the teacher profession. Sumiati (2007) explained that the competence of teachers covering aspects of them are: educational background, appearance, activities using procedures and techniques, and achievement of results. Competence is manifested in real work that is beneficial for oneself and the environment (Musfah, 2011). The dynamics that developed to this day that the competence of teachers give influences in the process of learning in the classroom. A professional teacher's ability is 
necessary, since in that context the teacher is not only in charge of the transfer of knowledge, but educates the main task. These more capabilities must be owned by teachers in generating quality future generations.

IPS subject teachers have tasks like other subjects, but the competencies of IPS teachers have their own standart. IPS teacher quality must be able to perform duties and obligations as an educator in school. The quality of professional IPS teachers are: broad and deep mastery of social sciences, mastery of profound field, attitude and ICT skill. One of the causes that indicates the lack of ability of teachers to produce adequate quality of students, the low ability and skills of teachers in teaching is often considered the factor causing the low achievement of educational outcomes (Agung, 2012). Teacher competency IPS is needed at junior high school level.Emplementation of the curriculum 2013 implements social science consisting of geographical, sociological, historical, and economic branches into integrated social studies subjects.

Problems arising from integrated IPS applications include graduates of IPS graduates are minimal and socialization from the government to the less junior high school. The impact of IPS teachers is difficult to increase the professionalism in the social sciences, considering that in all schools of SMP Negeri in Jember many teachers of study. The number of teachers in the field of study that many make professional teachers especially social science is not optimal.

Orentation of IPS lesson application is used to study the phenomenon of the past and the coming. The emphasis of study in the field of social studies in the curriculum needs to be done as a step to answer the problems of both phenomena. Optimization of IPS lessons for students to solve past and present problems. However, the application of IPS lesson needs to be supported with the competence of teachers relevant to the field of IPS.Based on data obtained by researchers from the Office of Education Jemberbahwa the number of teachers of SMP Negeri and Swasta as many as 386 teachers, while the number of IPS teachers in Jember District as many as 184 teachers. Teacher's last education average IPS in KabupatenJember is $96 \%$ strata S1, while S2 is only $4 \%$. Teachers of subjects at school have different educational backgrounds, if presented according to educational background such as: geography $20 \%$, sociology $8 \%$, history $21 \%$, economics $34 \%$, PKn2\%, $2 \%$ religious education, and IPS $13 \%$.Based exposure description on the background as follows: (1) How 
is the professionalism of IPS teacher in Jember Regency ?; (2) How to improve the competency of IPS teacher professionalism in Jember District. The formulation of the problem was aimed at this research which aimed at: (1) Knowing the condition of professional competence IPS teachers in Jember District; and (2) to know the effort of increasing the competence of IPS teachers in Jember District.

\section{METHODS}

The population in this study is all IPS teachers in Jember regency number 184. According to Arikunto (2006) that the sample is part or representative of the population studied. Sampling technique is done by random sampling. The sample used is SMP Negeri IPS teachers in Jember Regency taken $30 \%$ at random. So sample number 55 sample. Methods of data collection in this study using questionnaires and documentation. Method of data analysis using descriptive percentage. The variables in this study consist of two kinds of professionalism teacher IPS conditions in Jember District and efforts to increase the competency of teacher professionalism in Jember District.

\section{RESULTS AND DISCUSSION}

This study aims to determine the efforts of IPS teachers in improving the competence of professionalism in junior high school district Jember. Astronomically, Jember District is located at the point 113030 'to 114002'30"BT and 7059'6' 'to 8033'56' '. Administratively Jember Regency is located in the eastern part of East Java Province. 1. The Result of Research Analysis of Professional Condition of IPS Teachers in Jember Regency Based on the analysis of the results of the research using descriptive analysis, the professionalism condition of IPS teachers in Jember District is as follows: 21 respondents (38.18\%) with very high category, 29 respondents $(52.73 \%)$ high, and 5 respondents $(9.09 \%)$ low category. From the results of the analysis can be concluded that the ability of teachers in the learning process to students meet the standards of competence set in the national high standard that is equal to $88.17 \%$.

Mastery matters, concepts, and science that is Teachers IPSThe number of 55 respondents obtained a description of the mastery of materials, concepts, and science supporters IPS that diampu by teachers as follows: 45 respondents $(81.82 \%)$ with very high 
category, 5 respondents $(9.09 \%)$ high category, and 5responden $(9.09 \%)$ low category. The classical condition of mastery of the material, concepts and science that IPS teacher teachers $(87.25 \%)$ in the high category. Penguasaanyang associated with integrated social science does not experience constraints in delivery to students.

Based on the result of the research, it is known that 55 respondents give responses related to the competency standard competence and basic competency of student's subjects as follows: 27 respondents $(49,09 \%)$ with very high category, 21responden $(38,18 \%)$ high category, 5 respondents $(9,09 \%)$ low category, and 2responden (3.64\%) very low category. The classical percentage of standard competency and basic competence of subjects that is supported by social studies teachers $(87.05 \%)$ are high category. The development of learning tools has followed the development of the era and science of integrated IPS on the material taught to students.

Based on the results of the research in Table 4 it is known that the development of learning materials that IPS teachers are able to creatively as follows: 29 respondents $(52.73 \%)$ with very high category, 24 respondents $(43.64 \%)$ high category, 2 respondents (3.63\% ) low category. Classically the percentage of the development of learning materials that are able to IPS teachers creatively (92.04\%) included in the category tinggi.Pengembangan material with contextual problems in the field conducted by teachers IPS so that students can understand the material in depth.

Based on the results of the analysis of research results from 55 respondents obtained deskripsitentang efforts to improve the professionalism of IPS teachers in Jember District as follows: 5responden (9.09\%) with very high category, 42 respondents (76.36\%) high category, 8 respondens $(14.55 \%)$ low category. The conclusion obtained that overall the largest $(71.34 \%)$ has a high effort in improving the competence of professionalism in the field of integrated IPS.

To formulate aspects of competency in detail can be analyzed based on certain taxonomy according to Benjamin S. Bloom competence divided into three aspects, namely: competence in cognitive aspects (intelligence), competence in the affective aspects (feelings), competence in psychomotor aspects (Sumiati, 2007: 245). The competency detailed by Benyamin S. Bloom has been adjusted to his taxonomy create in learning theory. Bloom hopes for a teacher to run it the taxonomy he made must refer to the three aspects of his competence detail too. 
So that there is a match between learning theory and teacher competence, so that the teacher can run the learning process smoothly. Teacher competency will have an influence in the process classroom learning. Teachers need to have the ability to run his profession as an educator. Teacher competency in this case is not only just deliver the subject matter, but a teacher needs to have more ability than that. As a profession, there are a number competencies possessed by a teacher, namely pedagogic competence, personality competence, professional competence, and social competence community (Sanjaya, 2006: 18). Theoretically, the four competencies can be separated by one each other, but practically the actual four competencies it cannot be separated. The four types of competence intertwine each other in an integrated manner in the teacher. Teachers who are skilled at teaching of course you also have to have a good and social person adjustment in society.

The teacher is the most important component in a education. Without a teacher a learning will not work well. According to Dunkin there are a number of aspects that can affect quality the learning process is seen from the teacher factor, namely the teacher formative experience, teacher training experience, and teacher properties (Sanjaya, 2006: 53). These three indicators are the most important elements must be owned by a teacher. This is due to the three indicators contains teacher characteristics, namely experiences related to social and educational background and characteristics possessed by the teacher. The position of the teacher as one of the professions must indeed be recognized within people's lives. Teachers must be recognized as equal equal professions tall and sitting as low as other professions, like doctors, judges, prosecutors, accountants, architecture, and many others. As a profession, the teacher fulfills the five characteristics or characteristics inherent in the teacher, namely: first, it has a function and social significance for the community, felt benefits for the community. Second, demand certain skills obtained through an adequate process of education and training education institutions can be accounted for.

One characteristic of teachers as a very important profession is that teachers must have the ability in accordance with the competency standards that have been applied. Teacher competency will influence the learning process in the classroom. Teachers need to have the ability to carry out their profession as educators. Teacher competency in this case is not just conveying subject matter, but a teacher needs to have more ability than that. In general, the competence of a teacher refers to four factors, namely pedagogic competence, personality competence, professional competence, and community social competence (Sumiati, 2007: 242). These four factors are expected to be possessed by every teacher, including teachers of social science, abilities that are not necessarily owned by people who are not teachers. So that the teacher can carry out his duties properly. 


\section{CONCLUSION}

Based on the results of research and discussion that the average teacher IPS in Jember have a condition of professional competence in the high category. This is not separated from the efforts such as: the mastery of the material, the development of learning tools syllabus and RPP, the innovation of the use of IPS learning methods.

\section{REFERENCES}

Agung, Iskandar . 2012. Panduan Penelitian Tindakan Kelas bagi Guru. Jakarta: Bestari

Musfah, Jejen. 2011. Peningkatan Kompetensi Guru. Jakarta. Kencana Prenada.

Sanjaya, Wina. 2006. "Strategi Pembelajaran Berorientasi Standar Proses. Jakarta : Kencana Prenada Media

Sumiati. 2007. Metode Pembelajaran Pendekatan Individual. Bandung: Rancaekek Kencana 